\title{
THERMAL CHARACTERISATION STUDY OF TWO DISPOSABLE DIAPER BRANDS
}

\author{
Asiphile Khanyile ${ }^{1,2, \star}$, Guy Cubitt Caws ${ }^{2}$, S’phumelele Lucky Nkomo ${ }^{1}$ and Ntandoyenkosi \\ Malusi Mkhize ${ }^{3}$ \\ ${ }^{1}$ University of KwaZulu-Natal, Discipline of Geography, 238 Mazisi Kunene Road, Glenwood, 4041 Durban, KwaZulu Natal, South Africa \\ ${ }^{2}$ Ethekwini Municipality, Cleansing and Solid Waste - Education and Waste Minisation Section, 05 Koningkramer Road, New Germany, \\ 3610 Durban, KwaZulu Natal, South Africa \\ ${ }^{3}$ University of KwaZulu-Natal, Discipline of Chemical Engineering, 238 Mazisi Kunene Road, Glenwood, 4041 Durban, KwaZulu-Natal, \\ South Africa
}
Article Info:
Received:
19 July 2019
Revised:
4 October 2019
Accepted:
23 October 2019
Available online:
29 January 2020
Keywords:
Disposable diapers
Pyrolysis
Kinetic parameters
Friedman method
Kissinger method

\begin{abstract}
Disposable diapers have become a prominent feature of solid waste dumped in landfills. It is estimated that disposable diapers take anywhere between 300 to 500 years to decompose. Despite the associated environmental challenges, a plethora of studies show that disposable diapers have become a popular choice for parents when compared with cloth diapers. Disposable diapers are argued to be more convenient for parents because of their once-off use and super-absorbent ability, of which they are able to absorb 200-300 times the weight as compared to the cloth diapers. This study investigates thermal devolatilisation profiles of disposable diapers as well as their iso-conventional kinetic parameters, elemental and fractional composition. In this study, the two most dominant disposable diaper brands were sampled and analysed qualitatively and quantitatively. It was observed that the exterior fraction of both diapers showed a single peak devolatilisation at a temperature of around $500^{\circ} \mathrm{C}$, while the interior fraction showed two distinctive devolatilisation peaks observed below $400^{\circ} \mathrm{C}$ and above $500^{\circ} \mathrm{C}$. However, the pyrolysis heating rate produced no effect on the pyro-char fraction. Furthermore, the devolatilisation pathways of different types of disposable diaper fractions showed that there is a potential for conducting stepwise pyrolysis to promote fractional recovery of valuable products. Disposable diapers waste conversion can be better handled by separating the outer fraction (mainly fossil-based plastics and rubbery materials) from the inner fraction (mainly bio-based fibers and absorbents). It is further illustrated that the kinetic parameters, $\mathrm{E}$ and $\mathrm{k}$ are different for each disposable diaper fraction.
\end{abstract}

\section{INTRODUCTION}

Global economic growth and increasing population have led to a large amount of waste being generated. As a result, waste management systems have become overburdened and more complex to manage. As indicated by Chhabra et al. (2016), an approximated 1300 million tonnes of waste is generated each year globally in urban centres and this figure is expected to increase to 2200 million tonnes by 2025 . The challenge with increasing waste quantities is that many developing countries, particularly in Africa, are finding it very difficult to manage their waste. Africa is estimated to generate close to 125 million tonnes of municipal solid waste every year, of which only fifty-five percent of it is collected (Oelofse and Nahman, 2019). Oelofse and Nahman (2019) further argue that there will be an estimated thirty percent increase in the waste generation rate in
Africa between 2012 and 2025. The major concern is that investments in proper waste management and disposal facilities remain at the bottom of development priorities in many developing countries (Zurbrugg 2002, Marshall and Farahbakhsh, 2013, David et al.,2019, and Moore, 2019). According to Arenas et al. (2019:01), "waste management systems in developing economies are still insufficient and in some cases, cause environmental problems because waste tends to be unseparated and disposed of in open landfill sites." Landfilling, incineration and illegal dumping are the dominant methods of dealing with waste in many African countries (Achankeng, 2003, Williams, 2005, Zoeteman et al., 2010, Kazuva and Zhang, 2019, Kyere et al., 2019, and Oelofse and Nahman et al., 2019). A plethora of scholars (McKay, 2002, Hicks, 2007, Hristovski et al., 2007, Smyth et al., 2010, Topanou et al., 2011, Badgie et 
al., 2012, and Idowu, 2019) have cited the issue of poor waste characterisation as a major stumbling-block to waste management in Africa. Topanou et al. (2011) argue that waste characterisation remains the key prerequisite for effective waste management programs. For Africa to better manage and benefit from their waste sector, waste characterisation should be highly prioritised.

Research indicates that countries worldwide should direct their waste management efforts towards creating a circular economy, and in so doing, eliminate the huge environmental burdens associated with poor waste disposal systems (UNTHA UK, 2015). Hence, the present study forms part of the paradigm shift towards creating a "circular economy" through exploring the possibility to recover valuable resources from post-consumer products. In this study, selected brands of disposable diapers are assessed in order to investigate their potential for waste-to-energy recovery. Khoo et al. (2019) indicates that globally, disposable diapers (categories under municipal solid waste) account for approximately $13 \%$ of municipal waste dumped in landfills. Disposal diapers, have by far, become the more preferred product for parents when compared to cloth diapers (Krafchik, 2016, Khoo et al., 2019, and Mendoza et al., 2019). Disposable diapers are argued to be more convenient for parents because of their once-off use and super-absorbent ability, of which they are able to absorb 200-300 times the weight as compared to the cloth diapers. A study by Sheila (2016) revealed that a child uses between 6-8 disposable diapers a day, and this accumulates to an estimated 5500 diapers before potty training (18-30 months). Despite their demand, disposable diapers are cited as a major environmental problem and burden in the waste management system, especially in developing countries (Colon et al., 2011, Remigios, 2014, Hamad et al., 2014, and Khoo et al., 2019). Disposable diapers have become a threat to the natural environment, from both a manufacturing and disposal perspective. The process of manufacturing disposable diapers further contributes to the depletion of natural resources. For instance, disposable diapers are mostly manufactured using $70 \%$ wood pulp and $30 \%$ petroleum, of which the latter is regarded as a finite resource and its combustion contributes significantly to climate change, (Khoo et al., 2019). Scholars have argued that the superabsorbent polymer (SAP) inside disposable diapers can take close to 500 years to decompose (Colon et al., 2011, Remigios, 2014, and Khoo et al., 2019).

Currently, disposable diapers are discarded mainly through landfilling and incineration amongst other methods, which include composting and recovery of materials through recycling. However, Budyk and Fullana (2019:01), highlight that, "due to the high organic and water contents of used diapers, landfill disposal and incineration are not desirable options". Similarly, Liang et al. (2008) argued that the high levels of moisture inside disposable diapers would require more time and energy to evaporate, causing the incineration process to be very slow. On the other hand, Sun et al. (2016) dismissed the application of the incineration method, indicating that it produces substances such as dioxins which have a negative impact on the environment and human health. Composting and recycling of disposable diapers has been seen as more favoured disposal options, especially in developed countries (Mihajlović, et al., 2019). Despite this, constraints such as high technological costs and complex processes (CoIon, et al., 2011) are some of the drawbacks which add to the problem of managing disposable diapers. In light of the aforementioned, there is a need for researchers to look at alternative methods that are more environmentally friendly and economically beneficial in the management of disposable diapers.

In this study, kinetic pyrolysis is applied to the two most dominant disposable diaper brands in South Africa (Huggies and Pampers) in order to assess their potential of waste-to-energy production. Pyrolysis involves the thermochemical treatment of samples in the absence of oxygen at elevated temperatures, and during this process, multiple reactions occur, (Apaydin-Varol et al., 2014, Heydari et al., 2015, Perera and Narayana, 2018). In addition, pyrolysis is also known for its production of pyro-gas, pyro-oil, and pyro-char (Heydari et al., 2015). Furthermore, Aboulkas et al. (2010:1363) highlighted that, "the first step for a suitable design of any polymer reactor is knowledge of the kinetics." Hence, the present study uses pyrolysis to understand the thermal behaviour of devolatilisation patterns of disposable diapers. Sharifzadeh et al. (2019) explains that the important characteristic of pyrolysis technologies is their adaptability and flexibility to accept a diverse range of raw materials.

The present study therefore aims to use the model-free iso-conversional (Friedman and Kissinger) methods to identify a pyrolysis reaction model. Additionally, "iso-conversional methods have the potential to determine the behaviour of complex reactions because they are simpler in nature and they decrease the risks of selecting an unsuitable kinetic model and of finding the wrong kinetic parameters", (Arenas et al., 2019:02). It has been mentioned above that most of the work has focused mainly on landfilling or incinerating disposable diapers; however, little attention is given to using thermochemical treatment as an alternative method. Thermogravimetric analysis (TGA) is performed to better understand the devolatilisation patterns of disposable diapers. Therefore, this study will apply kinetics in order to pursue the possibility of using this method as a future means of safely managing disposable diapers.

\section{THEORETICAL BACKGROUND}

The general material devolatilisation mathematical relationship is presented as follows:

$\frac{d m}{d t}=k(T) f(m)$

where: $m$ is a mass fraction, $t$ is time, $k(T)$ is reaction rate constant at temperature, $\mathrm{T}(\mathrm{K})$, and $\mathrm{f}(\mathrm{m})$ is the reaction model.

The time, $t$, and heating rate, $\beta$, can be related by Eq. (2). $\beta=\frac{d T}{d t}$

where: $\beta$ is the heating rate, and $T$ is the absolute temperature. 

(3).

$$
k(t)=k_{0} \exp \left(\frac{-E_{a}}{R T}\right)
$$

where: $\mathrm{k}$ is the reaction rate constant, $\mathrm{k} 0$ is a pre-reaction rate constant, Ea is the activation energy, and $\mathrm{R}$ is the universal gas constant.

Therefore, by substituting Eq. (2) and Eq. (3) in Eq. (1):

$\frac{d \alpha}{d T}=\frac{1}{\beta} k_{0} \exp \left(-\frac{E_{a}}{R T}\right) f(m)$

\subsection{Determination of kinetic parameters}

The linear mathematical analysis methods for experimental results analysis were selected to estimate kinetic parameters ( $\mathrm{Ea}$ and $\mathrm{k} 0$ ). This approach has advantages in that it is a well-established conventional application in the analysis of thermal devolatilisation of solids. Non-isothermal pyrolysis conditions were used since the experiments were carried out at various heating rates $(10,20,30,40$ and $50^{\circ} \mathrm{C} / \mathrm{min}$ ). Iso-conversional methods of Friedman (differential approach) and Kissinger (integration approach) (Friedman, 1964; Kissinger, 1957) are used along with mathematical methods for the analysis of the experimental results.

\subsection{Friedman method}

In order to establish a linear relationship, a natural logarithm of Eq. (4) was employed in the equation and expressed in the following equation:

$\ln \left(\beta \frac{d \alpha}{d T}\right)=\ln k_{0}+\ln f(\alpha)-\frac{E_{a}}{R T}$

Plotting $\ln \left(\beta \frac{d \alpha}{d T}\right)$ versus $\frac{1}{T}$ at given reaction progress, $a$, for various heating rates yields a straight line with slope $\frac{-E_{a}}{R}$. Activation energy can be obtained from this slope without knowing the reaction function $f(a)$. The pre-exponential reaction rate constant, $k_{0}$, is the $y$-intercept of a straight line. Friedman method is one of the model-free iso-conversional methods (Friedman, 1964).

\subsection{Kissinger method}

As for the Kissinger method, temperature values at the maximum devolatilisation rate of diapers are at the various heating rates (Kissinger, 1957). In the Kissinger method, Eq. 4 is modified to Eq. (6).

$\ln \left(\frac{\beta}{T^{2}}\right)=\ln \left(\frac{k_{0} R}{f(\alpha)}\right)-\frac{E_{a}}{R T}$

A plot of $\ln \left(\frac{\beta}{T_{\max }^{2}}\right)$ versus $\frac{1}{T_{\max }}$ at various heating rates yields a straight line that allows determination of the activation energy, Ea, from the gradient of the straight line, $\frac{-E_{a}}{R}$. The $y$-intercept can be used to estimate the pre-exponential reaction rate factor. Similar to the Friedman method, the
Kissinger method is another example of a model-free isoconversional method.

\section{EQUIPMENT AND METHOD}

The samples of clean disposable diapers brands were collected from the Pinetown CBD and Clermont in the KwaZulu-Natal province, South Africa. Two diaper brands, namely, Huggies and Pampers, were used for the experiments. Two or more units for each brand were used as samples for proper representation and re-testing. Additionally, the diapers were sampled by hand separation (interior and exterior fractions) and were crushed by cutting into fine particles (diameter less than $1 \mathrm{~mm}$ ).

The proximate analysis was done using the thermogravimetric analysis, which was carried out on each diaper brand to determine the mass loss as temperature increases. The maximum temperature was set to $800^{\circ} \mathrm{C}$. Nitrogen $\left(\mathrm{N}_{2}\right)$ and Air were used as a carrier gas and a combustion median to trace the devolatilisation profile and to determine ash content, respectively. A TA 60WS model thermogravimetric analyser (TGA) (Shimadzu, Kyoto, Japan) was used for all experiments. The calculations were done using the Standard Test Method for Compositional Analysis by Thermogravimetry: Designation: ASTM E 1131 - 08, (2008).

\section{RESULTS AND DISCUSSION}

\subsection{Thermogravimetric analysis}

The disposable diapers brands samples were collected from the Pinetown CBD and Clermont areas in KwaZuluNatal, South Africa. The proximate analysis was carried out to determine the high volatile content, volatile matter, fixed carbon, and ash contents. The results of the proximate analysis are summarised in Table 1 below. Furthermore, the TGA/DTG graphs of the internal and exterior fractions of both brands are depicted in Figures 1, 4, 6 and 9.

The TGA results in Table 1 reveal that the interior fractions of both disposable diaper brands are higher in terms of the high volatile matter contents as compared to the exterior fractions. For instance, the Huggies interior fraction was at $14.74 \mathrm{wt}$. \% whist the exterior had $0.22 \mathrm{wt} . \%$. On the other hand, the Pampers brand had 8.09 wt.\% in the interior, and only $0.67 \mathrm{wt} . \%$ was contained in the exterior fraction. These high volatile matter contents in the interior fraction can be attributed to the materials inside the disposable diapers. The inner core layer is made up of SAP and wood pulp which are major absorbents of water, resulting in diapers being heavier as well (Wolston, 2015). Figures 1 and 6 depict the interior fractions of both diaper brands, which is significantly different from the exterior fraction de-

TABLE 1: Proximate analysis of the interior and exterior fraction of disposable diaper brands.

\begin{tabular}{|c|c|c|c|c|c|c|c|c|}
\hline \multirow{2}{*}{$\begin{array}{c}\text { Disposable } \\
\text { Diaper Brands }\end{array}$} & \multicolumn{4}{|c|}{ Interior fraction (wt.\%) } & \multicolumn{3}{|c|}{ Interior fraction (wt.\%) } & \multirow[b]{2}{*}{ Ash } \\
\hline & $\begin{array}{c}\text { High } \\
\text { Volatile }\end{array}$ & $\begin{array}{l}\text { Volatile } \\
\text { matter }\end{array}$ & $\begin{array}{l}\text { Fixed } \\
\text { carbon }\end{array}$ & Ash & $\begin{array}{c}\text { High } \\
\text { volatile }\end{array}$ & $\begin{array}{l}\text { Volatile } \\
\text { matter }\end{array}$ & $\begin{array}{l}\text { Fixed } \\
\text { Carbon }\end{array}$ & \\
\hline Huggies & 14.74 & 61.54 & 10.63 & 13.09 & 0.22 & 88.82 & 8.54 & 2.42 \\
\hline Pampers & 8.09 & 67.54 & 11.63 & 12.74 & 0.67 & 94.57 & 3.14 & 1.62 \\
\hline
\end{tabular}




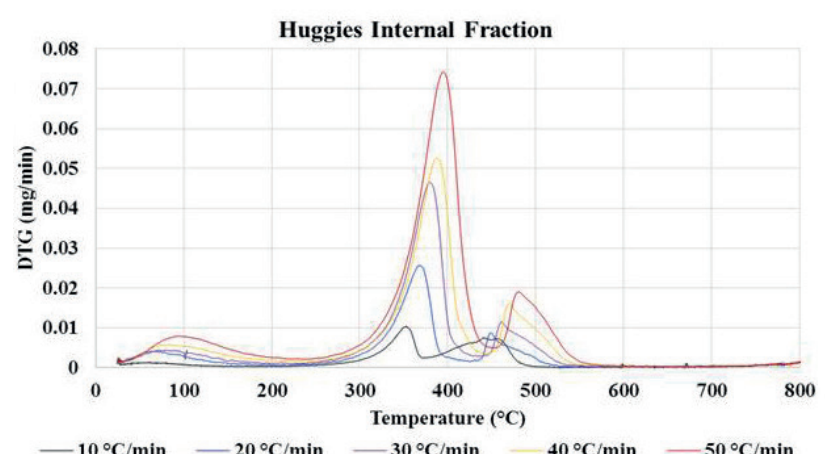

(a)

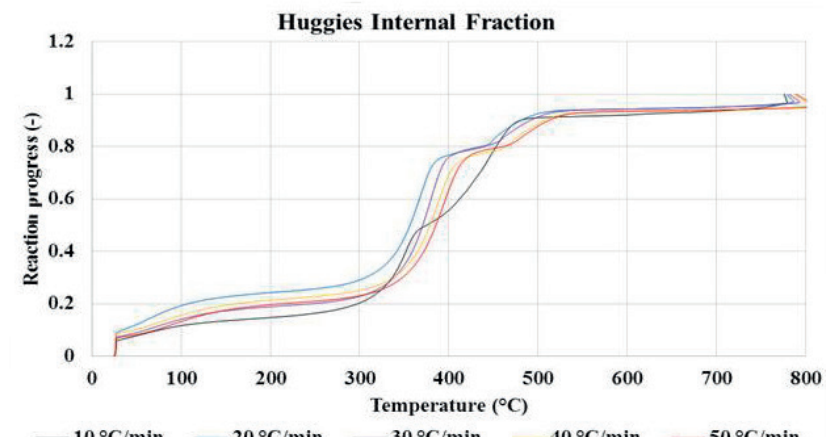

(c)

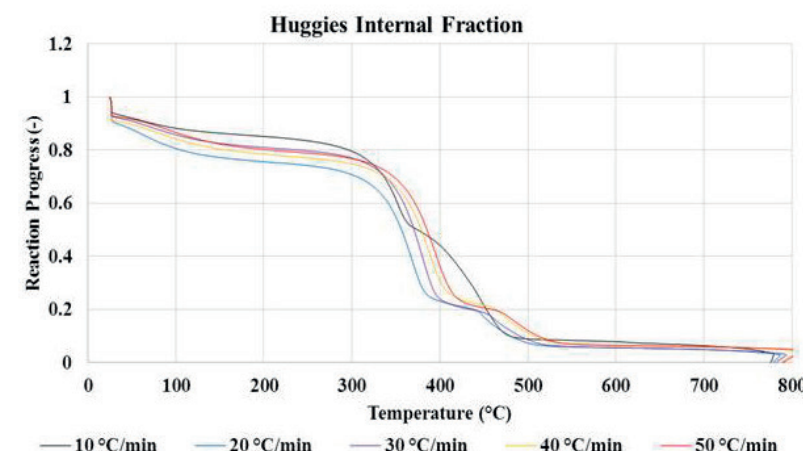

(b)

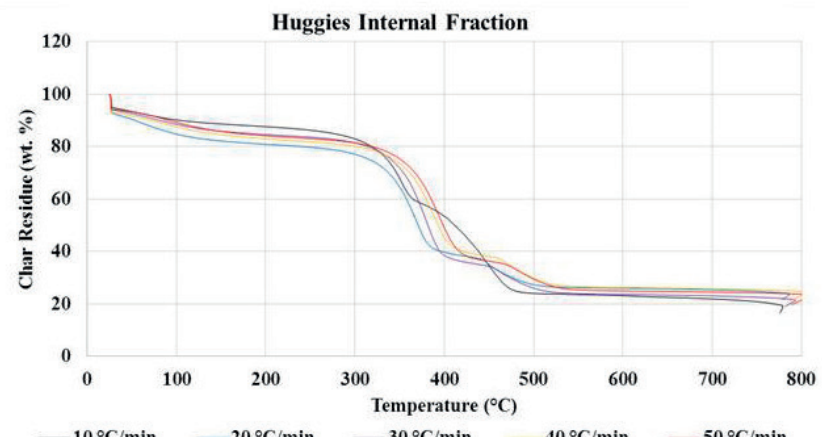

(d)

FIGURE 1: Huggies Internal Fraction derivative thermogravimetric analysis (DTG), reaction progress (a) and char residue profiles.

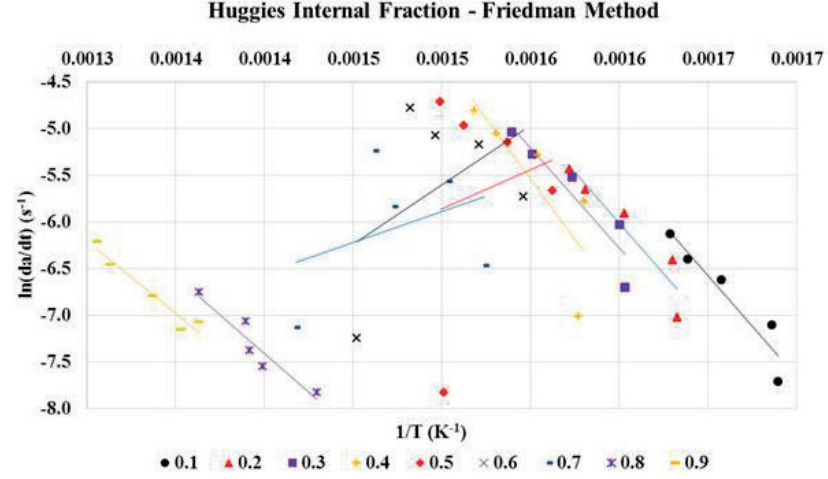

(a)

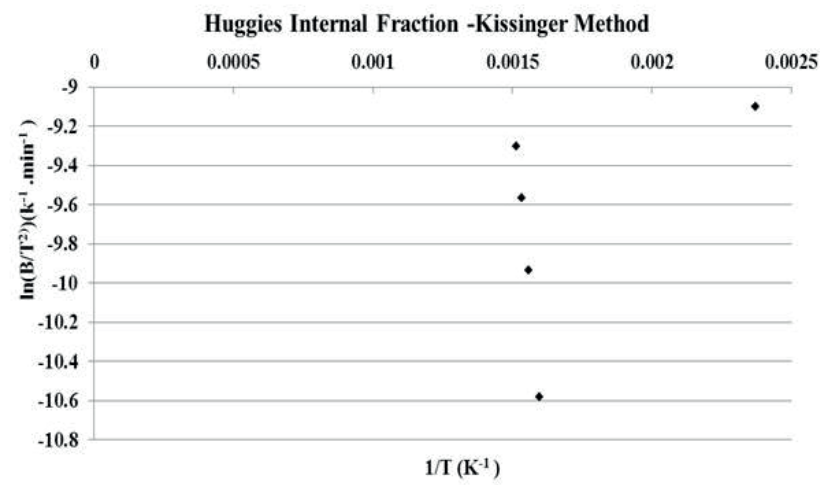

(c)

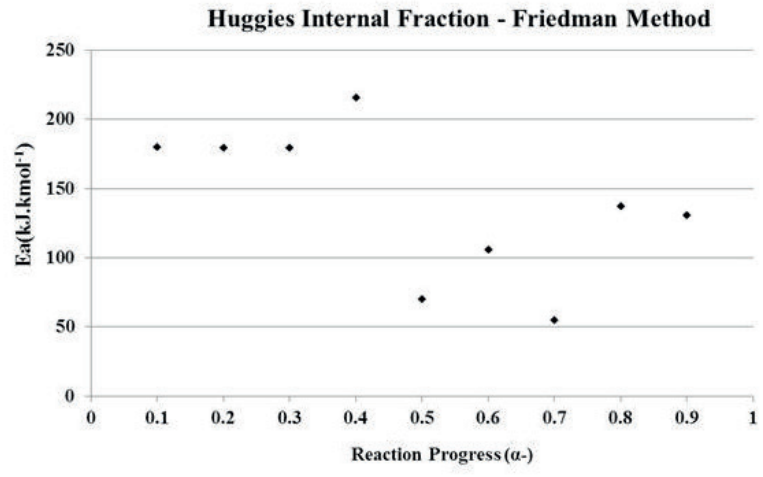

(b)

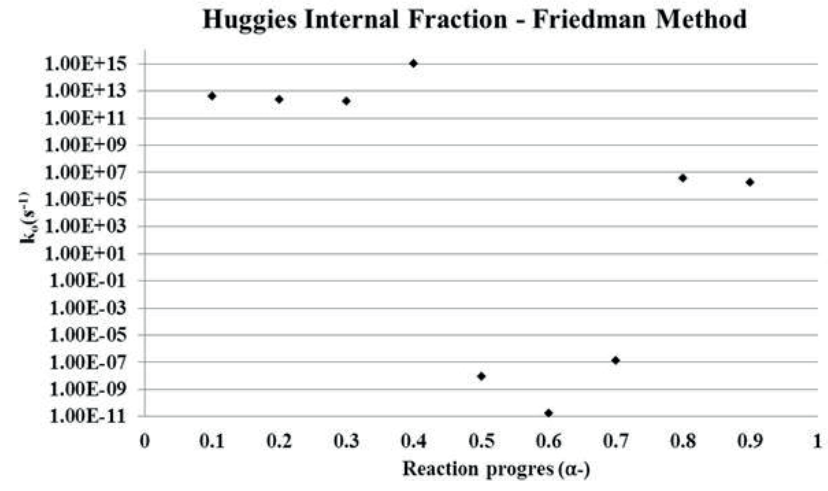

(d)

FIGURE 2: Huggies Internal Fraction kinetic parameters profiles (Friedman and Kissinger Methods). 
picted in Figures 4 and 9. The latter shows each brand with two distinctive peaks, between the temperatures of $350^{\circ} \mathrm{C}$ and $480^{\circ} \mathrm{C}$.

The exterior fractions of both diaper brands are highlighted in Figures 4 and 9, which only show single peaks, especially around the temperatures of $450^{\circ} \mathrm{C}$ and $500^{\circ} \mathrm{C}$. This could be attributed to the fact that the exterior fraction is lighter in weight and contains mostly plastics. In addition, this is also the main devolatilisation stage, where the volatile matter is released. Thus, it is also supported by results in Table 1, which shows the exterior fractions of both brands with a higher volatile matter. The exterior fraction in Table 1 highlights that a volatile matter for Huggies is 88.82 wt. \% and for Pampers it is 94.57 wt.\%, which are both higher than the interior fraction. The final devolatilisation zone is observed where the fixed carbon and ash are released. According to Heydari et al. (2015), the lower devolatilisation rates observed can attribute to further gasification and char released at elevated temperatures.

\subsection{Elemental analysis}

The results in Table 2 below highlight the ultimate analysis, which was carried out to determine the carbon, nitrogen, hydrogen, and sulphur contents. However, only two components were obtained from the Huggies and Pampers diaper brands, namely carbon and hydrogen. From Table 2, it is observed that the Pampers diaper brand had a higher concentration of carbon and hydrogen for both the interior and exterior fraction. Table 2 notes that the exterior fraction had the highest carbon and hydrogen contents. For example, the Huggies brand had 75.89 wt.\% of carbon whilst the Pampers brand had 78.29 wt.\%. A similar pattern is observed with hydrogen where the Huggies diaper brand had 11.41 wt.\% and Pampers had 11.83 wt.\%. As a result, these observations can be supported by the results found in Figures 4 and 9 which show the major difference in the devolatilisation patterns of the exterior fractions of both diaper brands.

\subsection{Kinetics analysis}

The results obtained from the thermogravimetric analysis are important because they were used to obtain the activation energies for disposable diapers pyrolysis.

Hence, kinetics were used to determine the conditions at which pyrolysis of disposable diapers could take place. Kinetics aided with the investigation to establish the reactions of both diaper brands (Huggies and Pampers). Since disposable diapers contain fluff pulp polymer, super-absorbent gel crystals and plastics (polyethylene), these could react differently to experimental design. Hence, Apaydin-

TABLE 2: Proximate analysis of the interior and exterior fraction of disposable diaper brands.

\begin{tabular}{l|c|c|c|c} 
& \multicolumn{2}{c}{ Interior fraction } & \multicolumn{2}{c}{ Exterior fraction } \\
\cline { 2 - 6 } & $\begin{array}{c}\text { Carbon } \\
\text { (wt.\%) }\end{array}$ & $\begin{array}{c}\text { Hydrogen } \\
\text { (wt.\%) }\end{array}$ & $\begin{array}{c}\text { Carbon } \\
\text { (wt.\%) }\end{array}$ & $\begin{array}{c}\text { Hydrogen } \\
\text { (wt.\%) }\end{array}$ \\
\hline Huggies & 37.35 & 5.45 & 75.89 & 11.41 \\
\hline Pampers & 54.12 & 7.93 & 78.29 & 11.83 \\
\hline
\end{tabular}

Varol (2014) highlights that this data, can be used to predict the kinetics of the devolatilisation patterns and hence, may give an idea about the thermal behaviour of polymeric substances during pyrolysis that may be a useful data for further reactor design.

In the current study, kinetic parameters were determined by two different methods that are explained in the above subsections (subsections 2.3.2 and 2.3.3). Both the model-free iso-conversional method, differential approach (Friedman) and integration approach (Kissinger) were used. Thus, in order to get the most appropriate thermal process (pyrolysis), different heating rates of $10,20,30,40$, and $50^{\circ} \mathrm{C} / \mathrm{min}$ were used in the experiments.

\subsection{Friedman method}

The Friedman method was used to obtain the activation energy $\left(E_{a}\right)$ of the thermal heating using peak values on the curves as indicated in Figures, 2, 5, 7, and 10, where the internal and external fractions of both disposable diapers brands are depicted. It is observed that the Huggies diaper brand had higher activation energies, especially in the interior fraction. For instance, the results in Figure 2 highlight that the activation energy for Huggies internal fraction ranges from $215.755 \mathrm{~kJ} / \mathrm{mol}$ to $55.329 \mathrm{~kJ} / \mathrm{mol}$. However, Figure 7 depicts that the Pampers diaper has a lower range of activation from $196.556 \mathrm{~kJ} / \mathrm{mol}$ to 5.068 $\mathrm{kJ} / \mathrm{mol}$. As a result, the Huggies brand in Figure 2 exhibits a non-linear pattern with conversion 0.1 to 0.4 higher than those of 0.5 to 0.9. However, the results in Figure 7 of the Pampers internal fraction show a V-shaped pattern, where conversion 0.5 is the lowest and conversion 0.8 with 0.9 is the highest. This indicates that where there is low activation energy it may be in the sensitive areas in the Friedman method.

In addition, the interior fraction has Peak 1 and Peak 2 of both diaper brands. The Friedman method shows a linear pattern, especially in Peak 1 of the Huggies internal fraction. This pattern is observed in Figure 3. In addition, Peak 2 of the Huggies internal fraction exhibits a rather non-linear pattern. On the other hand, the Pampers diaper brand Peak 1 and 2 of the internal fractions are shown in Figure 8.

The exterior fraction of the Huggies brand had higher activation energy ranging from $161.716 \mathrm{~kJ} / \mathrm{mol}$ to 138.559 $\mathrm{kJ} / \mathrm{mol}$, whilst the Pampers brand had ranges of 147.357 $\mathrm{kJ} / \mathrm{mol}$ to $93.360 \mathrm{~kJ} / \mathrm{mol}$. Furthermore, Figure 5 of the Huggies diaper brand shows a linear pattern of the activation energy as compared to the Pampers brand in Figure 10 which has a less linear pattern.

\subsection{Kissinger method}

The Kissinger method of the interior fraction of both diaper brands is not in straight lines as compared to the exterior graphs. These results are observed in Figures 2 and 7. The results are further depicted in Table 3, which shows the char residue, where the exterior fractions have smaller contents as compared to the interior fractions. In addition, Table 3 also correlates with the results observed in Figures 2, 5, 7, and 10. The results shown in Figures 3 and 8 of the interior fraction of both diapers highlight Peak 


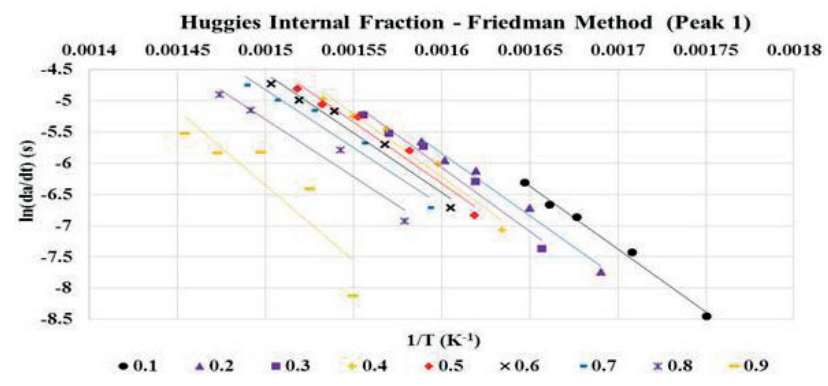

(a)

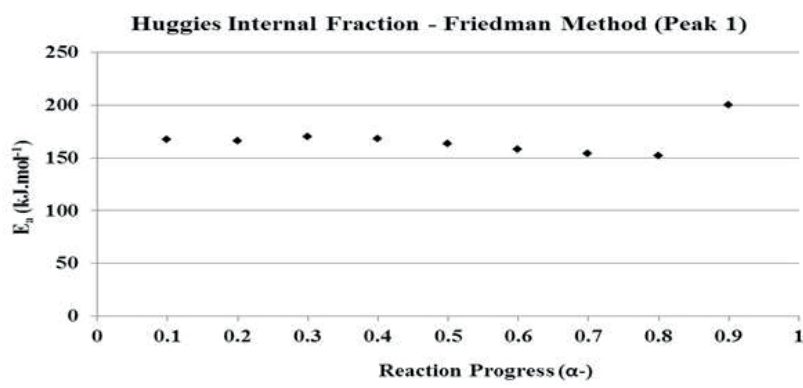

(c)

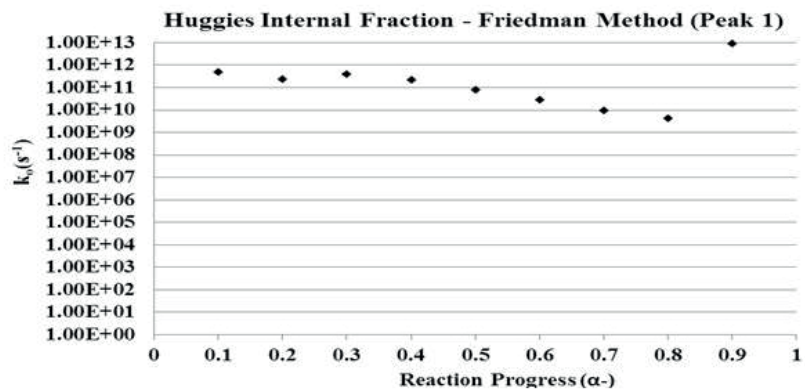

(e)

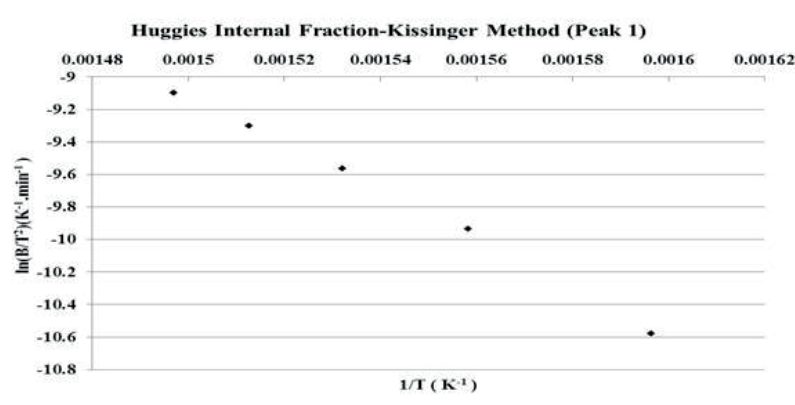

(g)

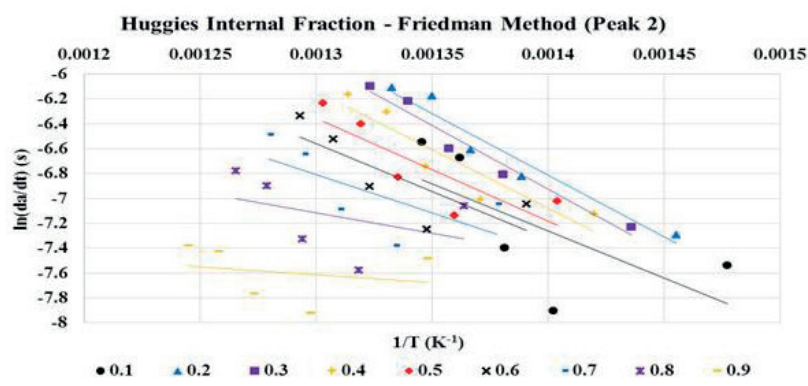

(b)

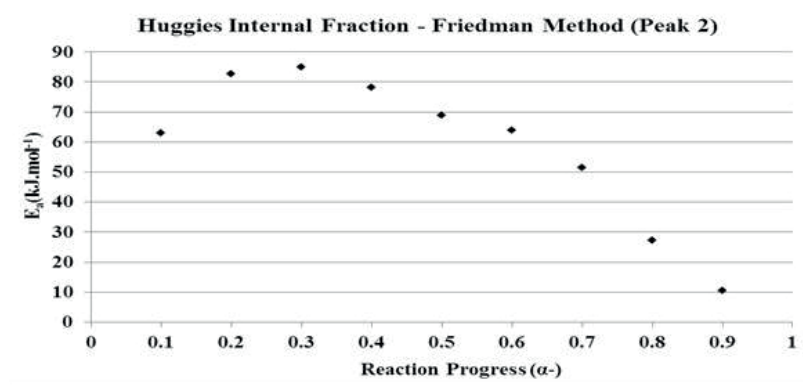

(d)

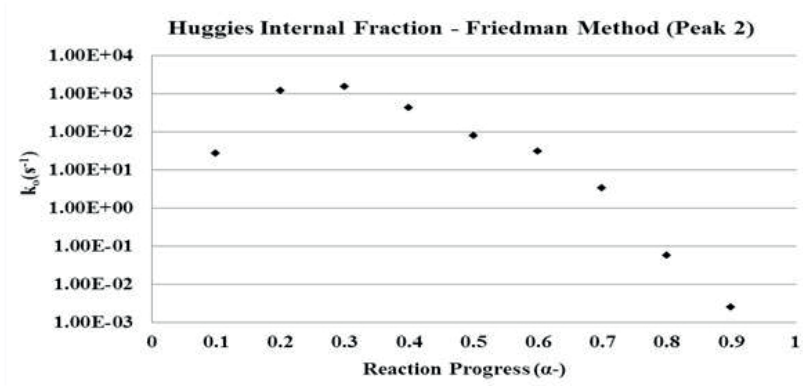

(f)

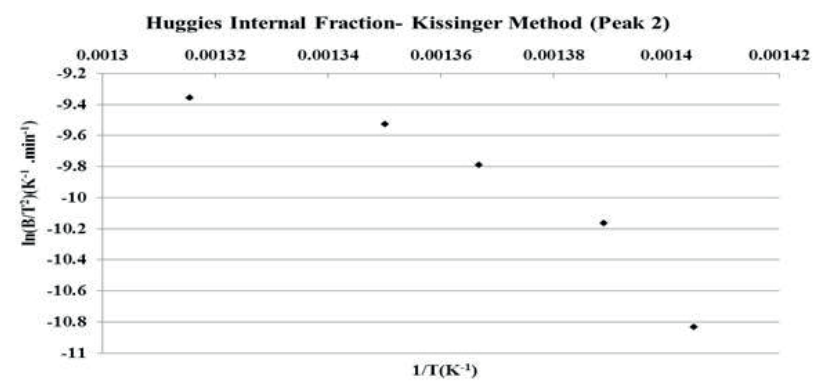

(h)

FIGURE 3: Huggies Internal Fraction two evolved peaks profiles (Friedman and Kissinger Methods).

1 with a straight line pattern as compared to Peak 2. In addition, this shows that due to the super-absorbent gel crystals and fluff pulp, the interior fraction of the diapers still need to be split further and analysed separately.

The kinetic parameters estimated values for both the Huggies and Pampers brands are illustrated in Table 4. As seen in Table 4, the Kissinger method exhibits higher activation energy, particularly in the external fraction of the Huggies diaper brand. For instance, the ranges are $164.99964 \mathrm{~kJ} / \mathrm{mol}$ to $166.35620 \mathrm{~kJ} / \mathrm{mol}$. However, the external fraction of the Pampers brand shows higher activation energy in terms of the Friedman method. For exam- ple, the results in Table 4 depict the range as $159.71986 \mathrm{~kJ} /$ $\mathrm{mol}$ to $157.54123 \mathrm{~kJ} / \mathrm{mol}$ whereas, in terms of the internal fraction, for both diaper brands for the Friedman method, the activation energy is lower. The Huggies diaper brand was found at $141.35382 \mathrm{~kJ} / \mathrm{mol}$ whilst the Pamper brand was at $109.31620 \mathrm{~kJ} / \mathrm{mol}$.

The Kissinger method shows a dissimilar pattern from Friedman method in terms of activation energy. Table 4 indicates that the internal fraction of the Huggies diaper brand has relatively low activation energy of $6.58618 \mathrm{~kJ} /$ mol whilst the Pampers brand has $122.04952 \mathrm{~kJ} / \mathrm{mol}$. These results are also supported by the observation in Figure 


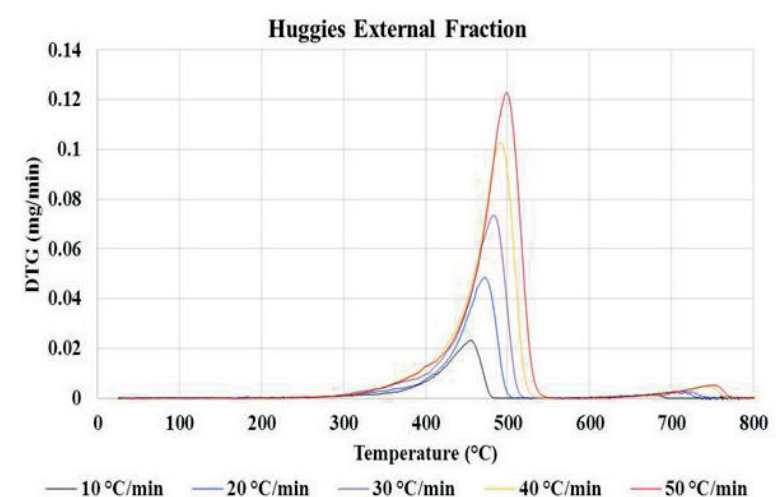

(a)

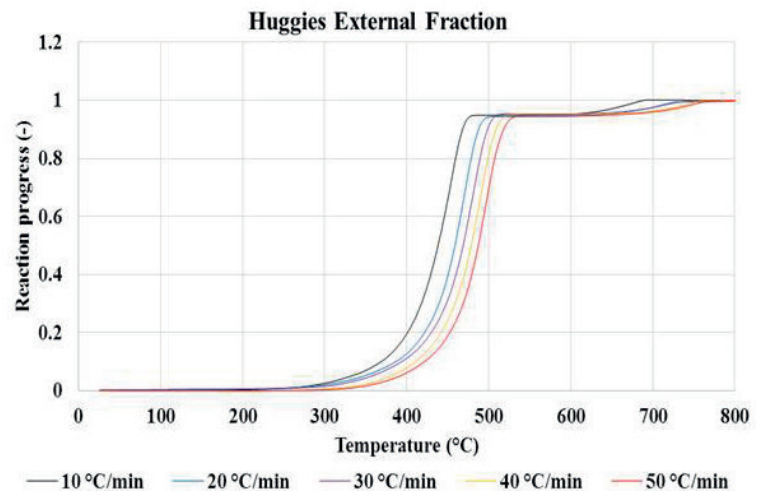

(c)

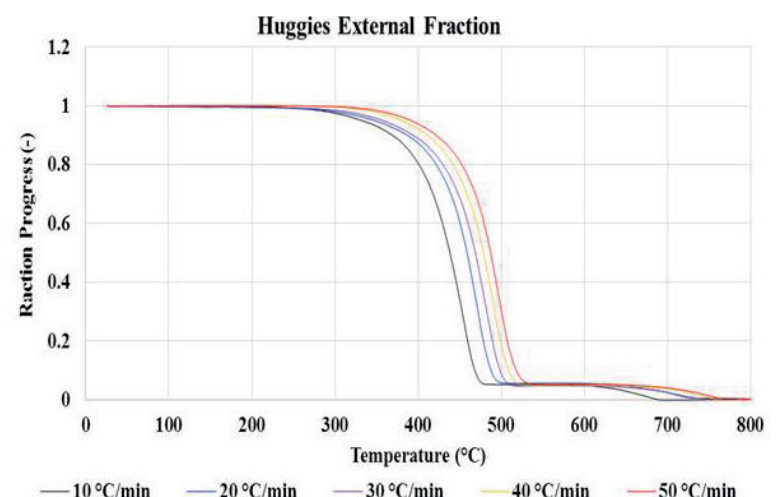

(b)

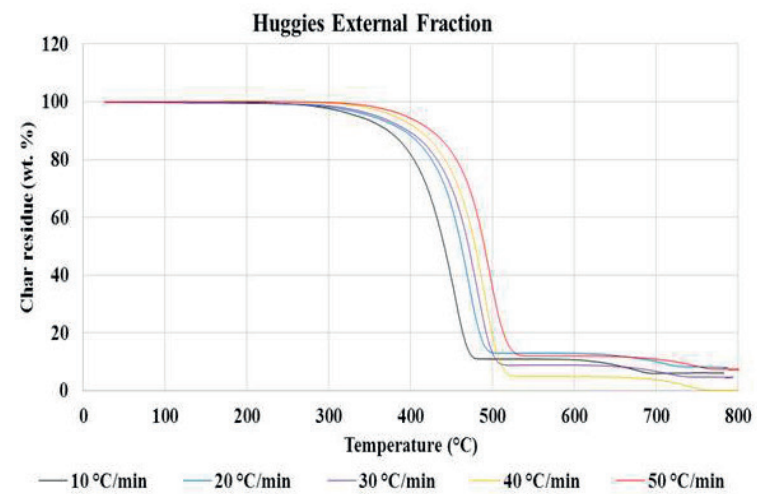

(d)

FIGURE 4: Huggies External Fraction derivative thermogravimetric analysis (DTG), reaction progress (a) and char residue profiles.

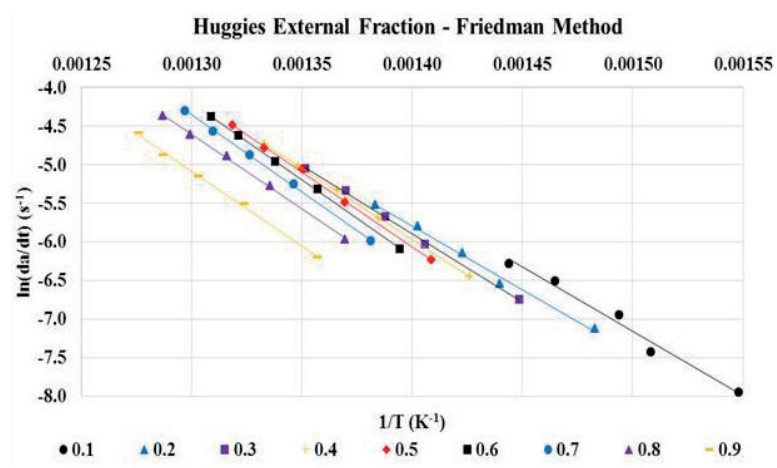

(a)

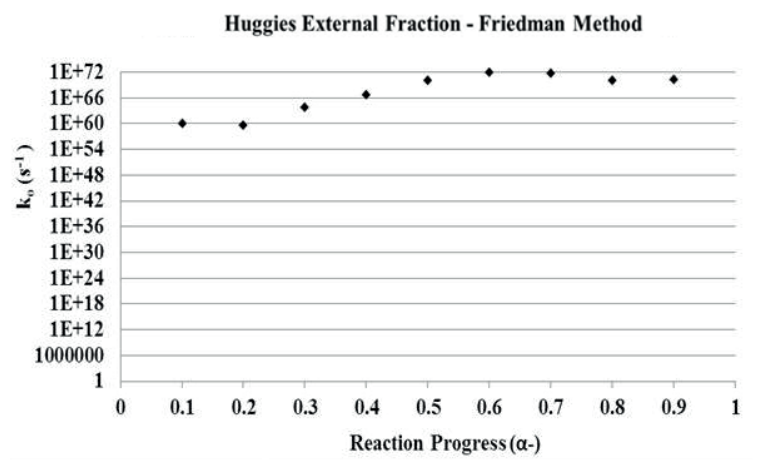

(c)

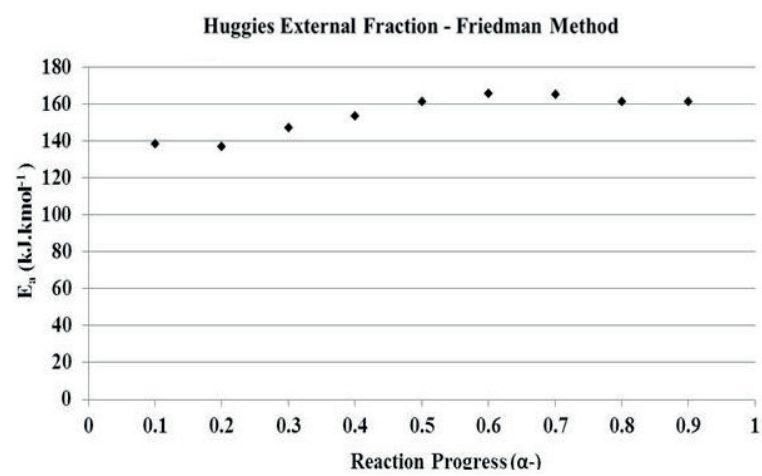

(b)

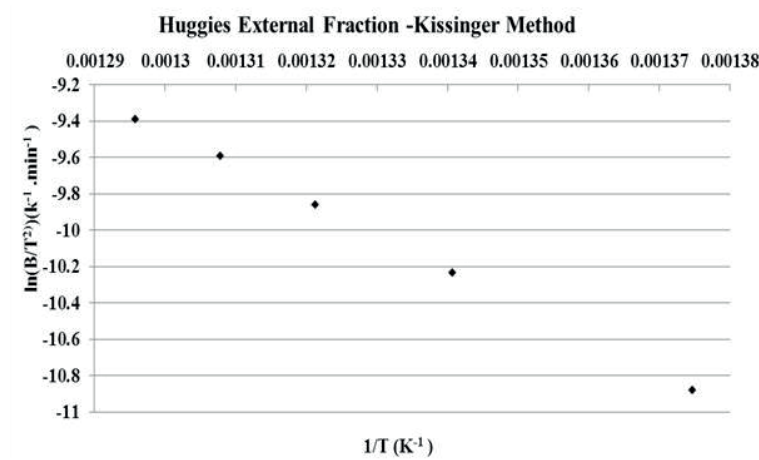

(d)

FIGURE 5: Huggies External Fraction kinetic parameters profiles (Friedman and Kissinger Methods). 


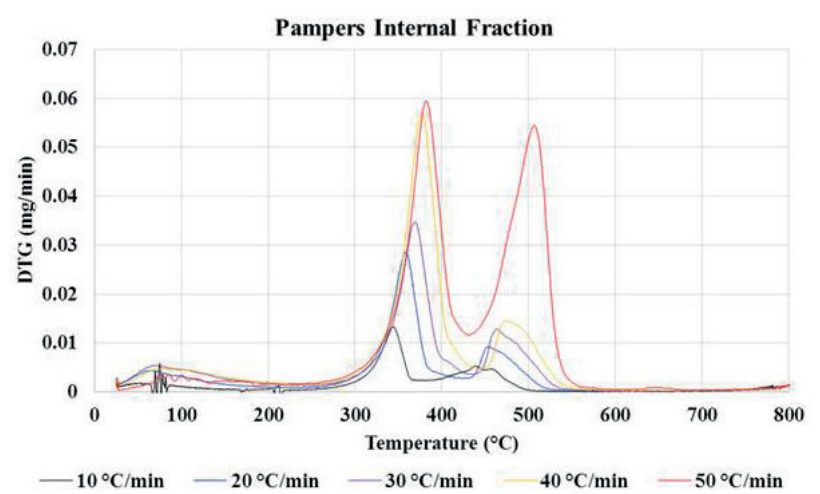

(a)

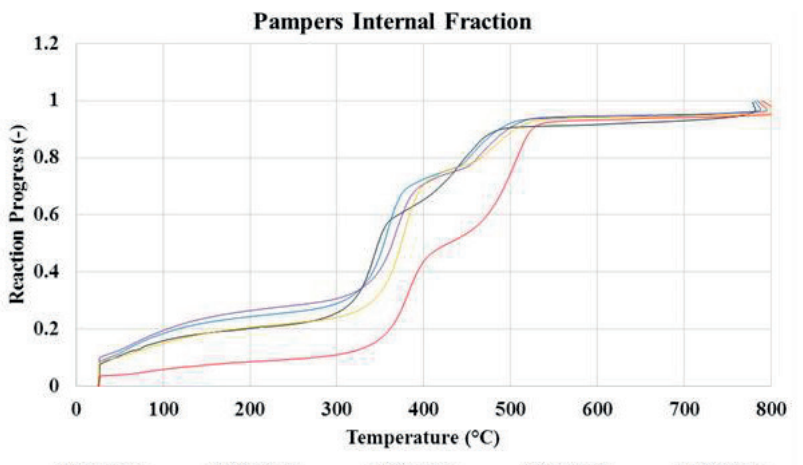

(c)

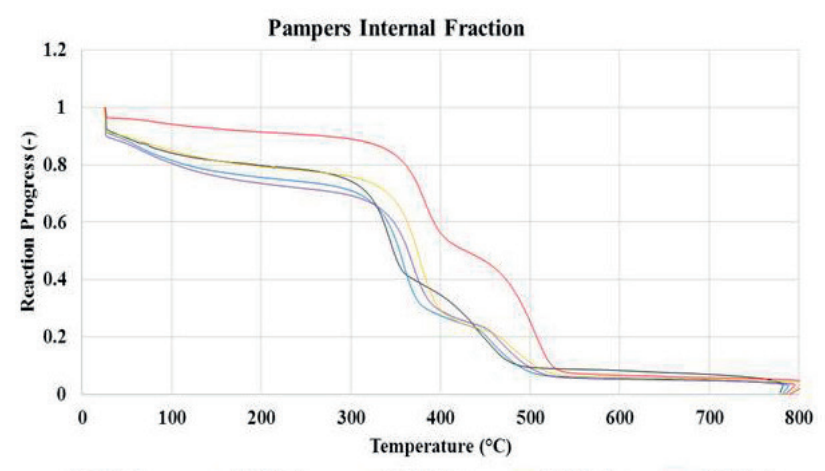

$-10^{\prime} \mathrm{C} / \mathrm{min}-20^{\circ} \mathrm{C} / \mathrm{min}-30^{\prime} \mathrm{C} / \mathrm{min}-40^{\circ} \mathrm{C} / \mathrm{min} \quad-50^{\circ} \mathrm{C} / \mathrm{min}$

(b)

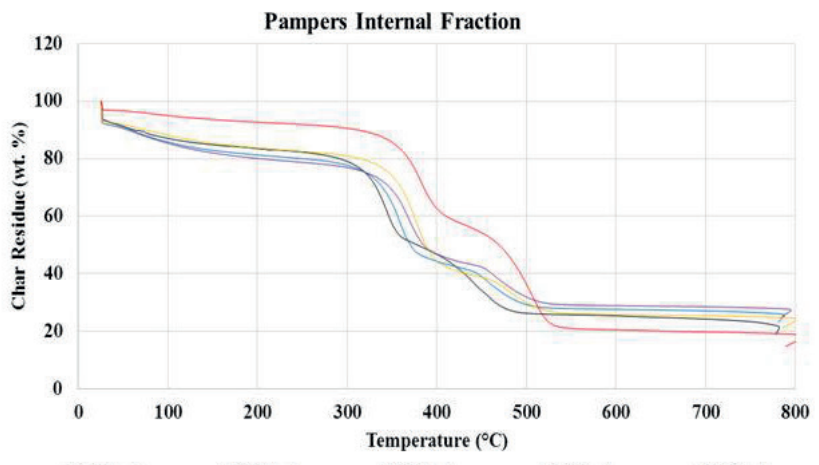

$-10^{\circ} \mathrm{C} / \mathrm{min} \quad-20^{\circ} \mathrm{C} / \mathrm{min} \quad-30^{\circ} \mathrm{C} / \mathrm{min} \quad 40^{\circ} \mathrm{C} / \mathrm{min} \quad-50^{\circ} \mathrm{C} / \mathrm{min}$

(d)

FIGURE 6: Pampers Internal Fraction derivative thermogravimetric analysis (DTG), reaction progress (a) and char residue profiles.

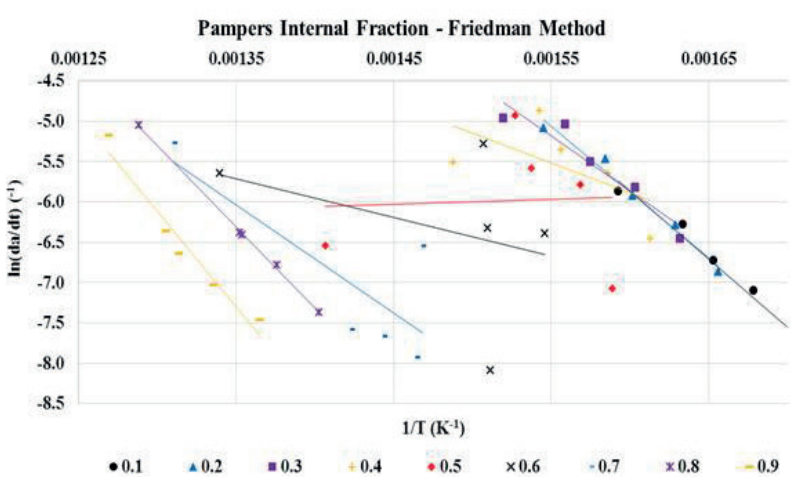

(a)

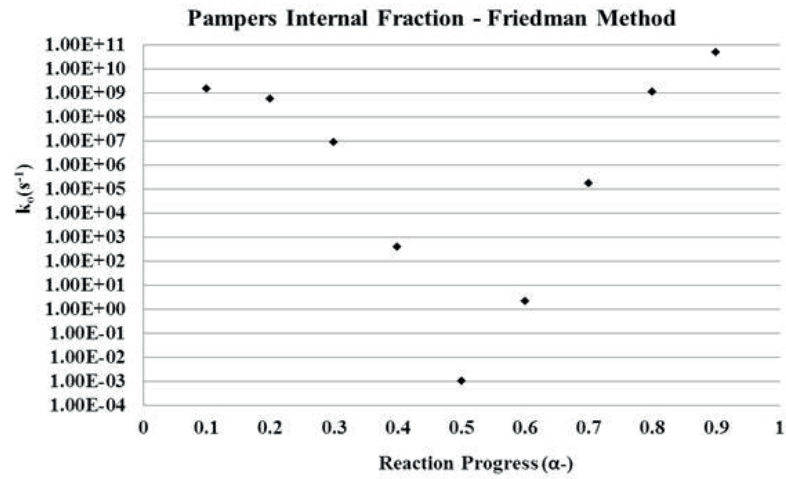

(c)

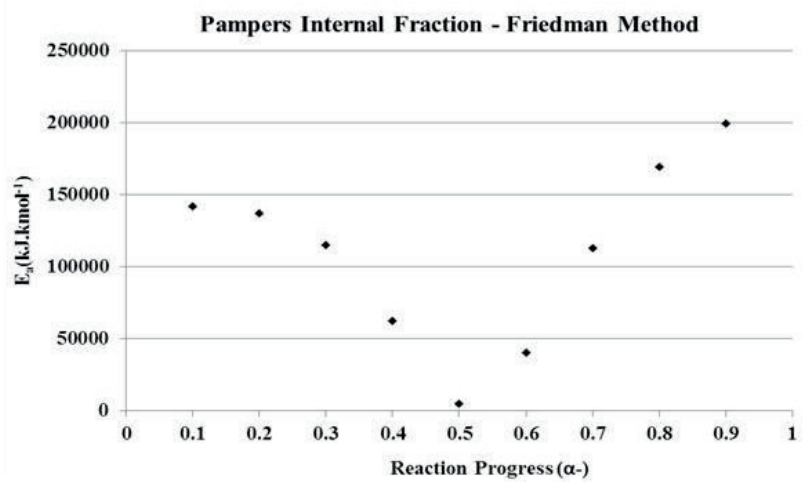

(b)

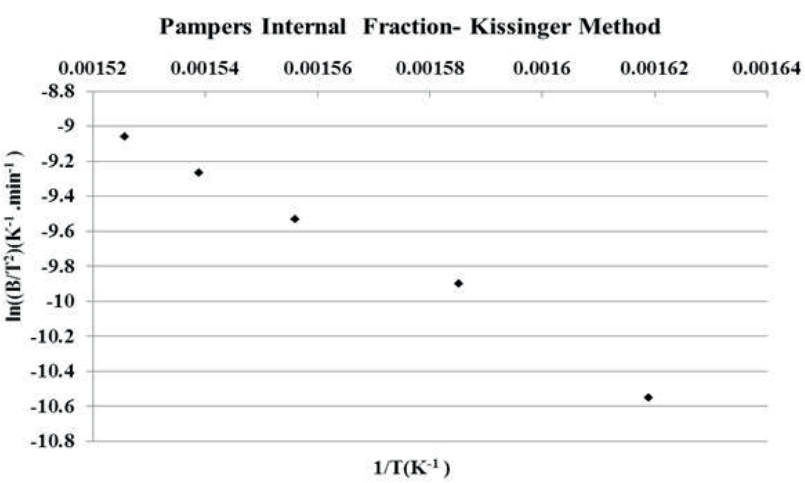

(d)

FIGURE 7: Pampers Internal Fraction kinetic parameters profiles (Friedman and Kissinger Methods). 


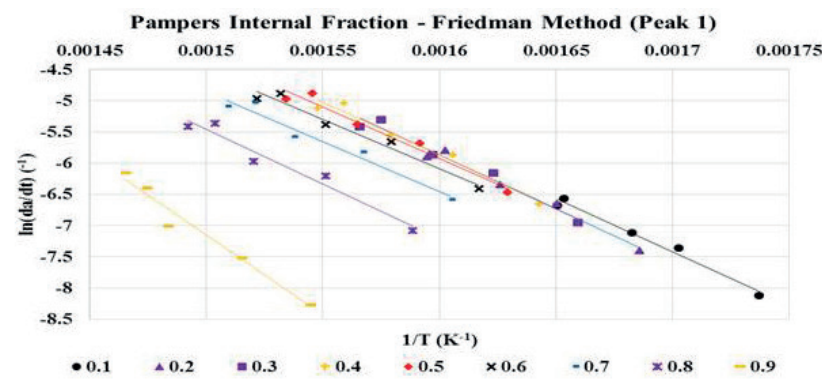

(a)

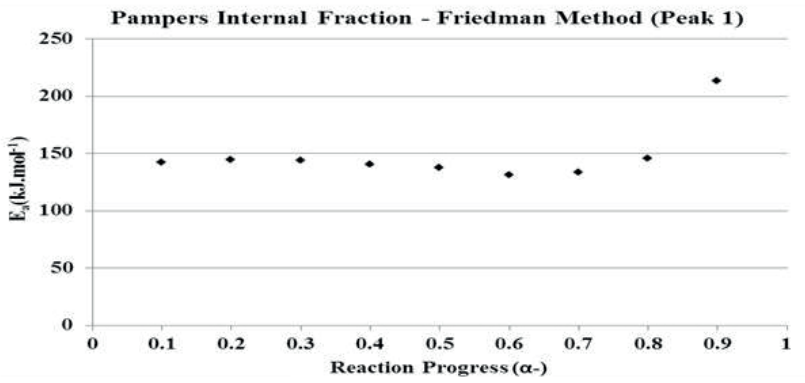

(c)

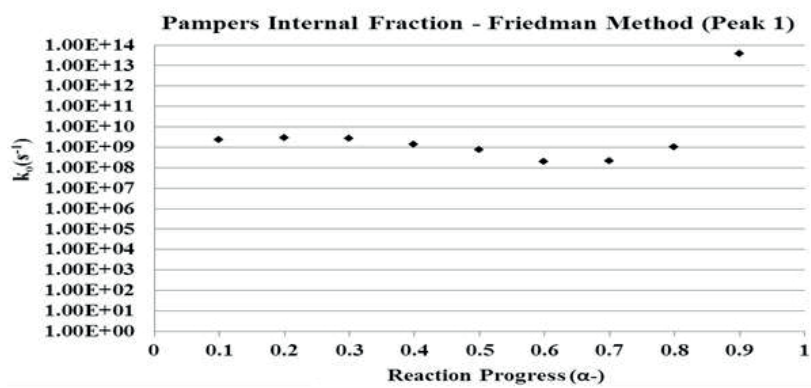

(e)

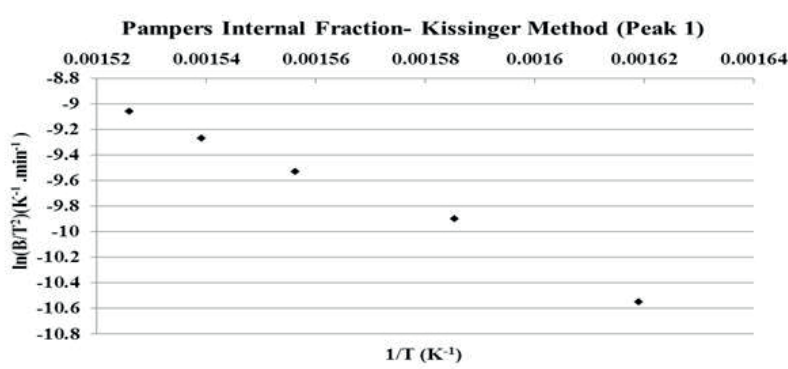

(g)

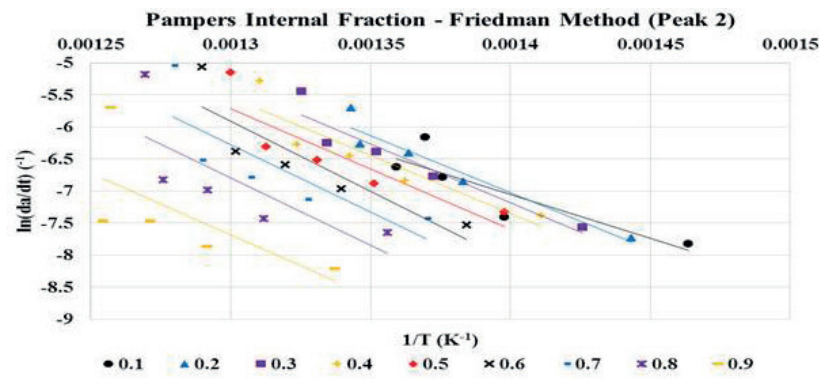

(b)

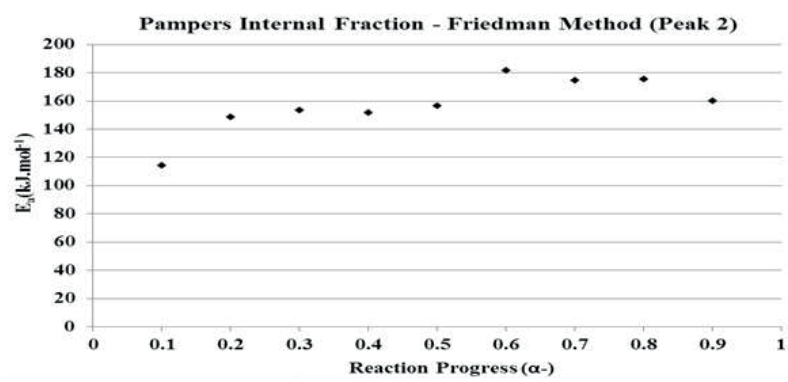

(d)

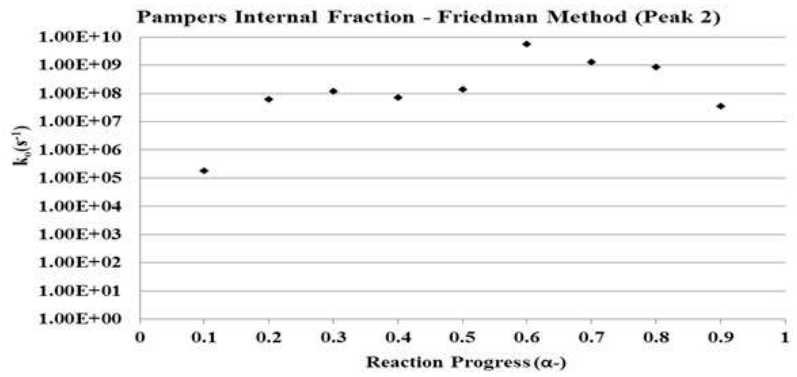

(f)

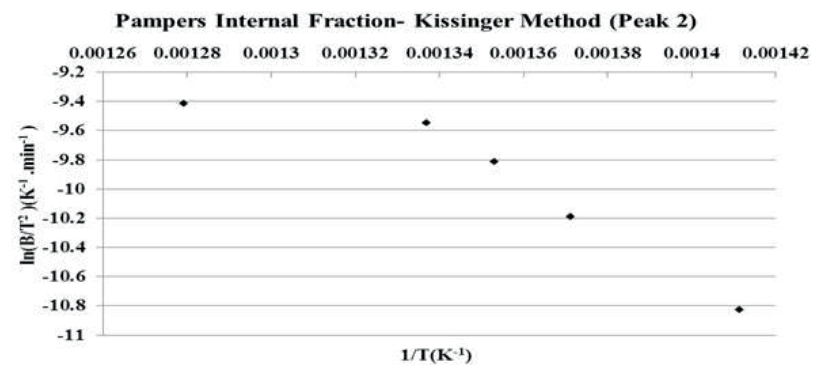

(h)

FIGURE 8: Pampers Internal Fraction two evolved peaks profiles (Friedman and Kissinger Methods).

2, where the Kissinger method of the Huggies brand depicts an unformed pattern.

Furthermore, the results in Table 4 also show the $\mathrm{k}_{0}$ estimation for both disposable diaper brands. Using the differential method (Friedman), the internal fraction of the Huggies diaper brand has a lower estimation as compared to the Pampers brand. The results are $1.29 \mathrm{E}+14 \mathrm{k}_{0}$ for the Huggies diaper brand whilst the Pampers brand had $5.81 \mathrm{E}+09 \mathrm{k}_{0}$. A similar pattern is observed for Peak 1 in Table 4. The Huggies brand shows the estimation of $k_{0}$ ranging from $1.20 \mathrm{E}+12 \mathrm{k}_{0}$ to $3.82 \mathrm{E}+02 \mathrm{k}_{0}$. On the other hand, the results in Table 4 illustrate that the Pampers diaper brand shows Peak 1 with higher estimations of $4.55 \mathrm{E}+12$ $\mathrm{k}_{0}$ and $9.08 \mathrm{E}+08 \mathrm{k}_{0}$.

The integration method (Kissinger) shows the internal fraction of the Pampers brand with higher estimations of $1.85 \mathrm{E}+40 \mathrm{k}_{0}$ and $1.59 \mathrm{E}+05 \mathrm{k}_{0}$ for the Huggies brand. Finally, the results in Table 4 also depict that, the Huggies brand, in the interior and exterior fractions, has a minimal gap. For example, the Huggies brand had estimations of $1.59 \mathrm{E}+05$ $\mathrm{k}_{0}$ and $1.56 \mathrm{E}+70 \mathrm{k}_{0}$. However, the Pampers diaper brand had estimations of $1.85 \mathrm{E}+40 \mathrm{k}_{0}$ and $1.10 \mathrm{E}+07 \mathrm{k}_{0}$. The integration (Kissinger) method is dependent on heating rates while the other is based on differentiation (Friedman). The- 


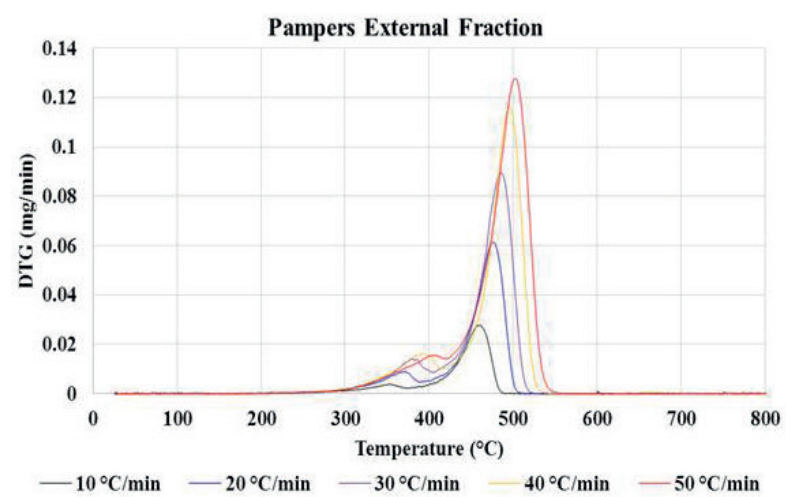

(a)

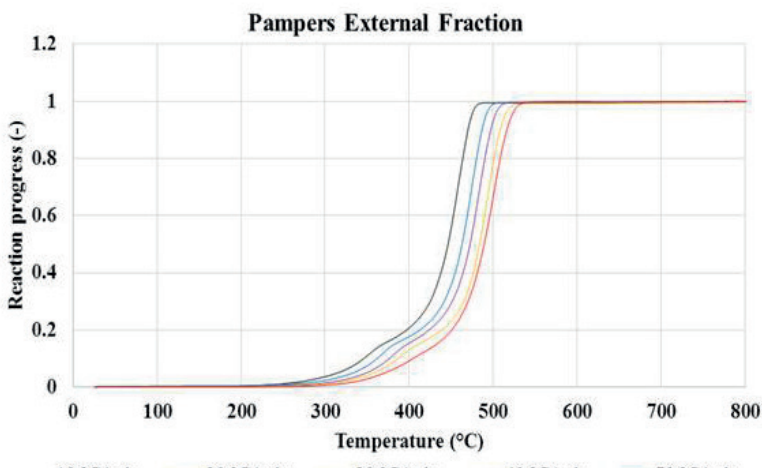

(c)

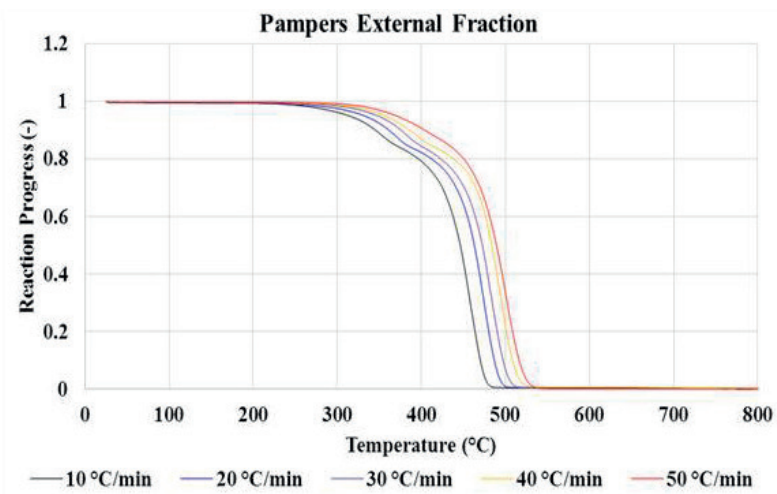

(b)

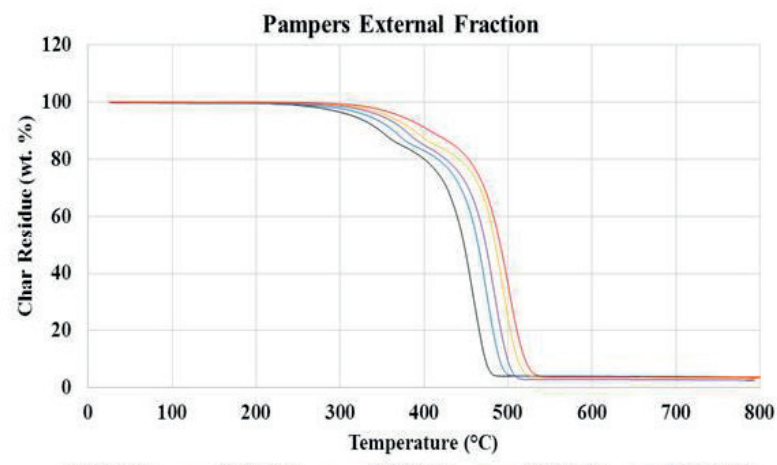

(d)

FIGURE 9: Pampers External Fraction derivative thermogravimetric analysis (DTG), reaction progress (a) and char residue profiles.

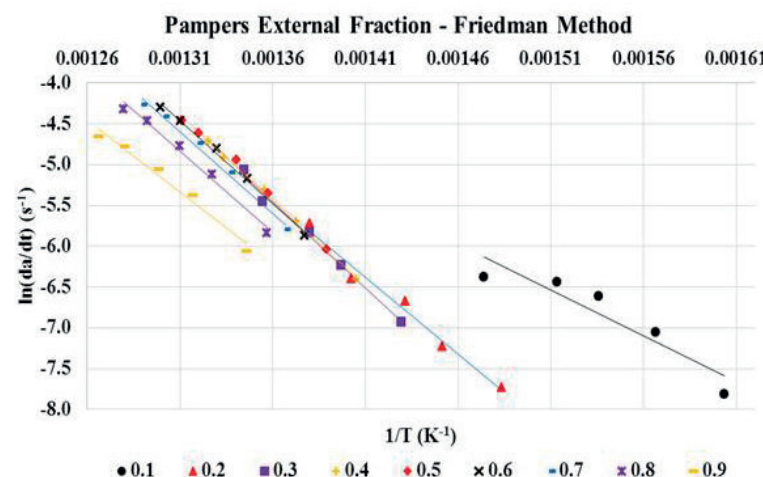

(a)

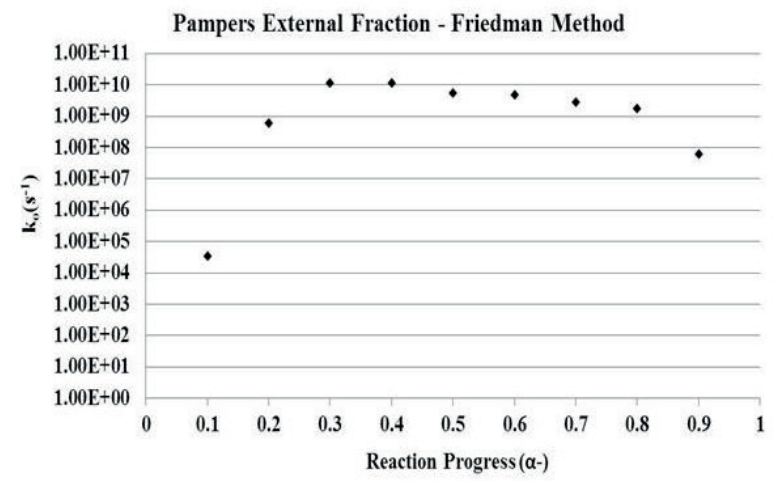

(c)

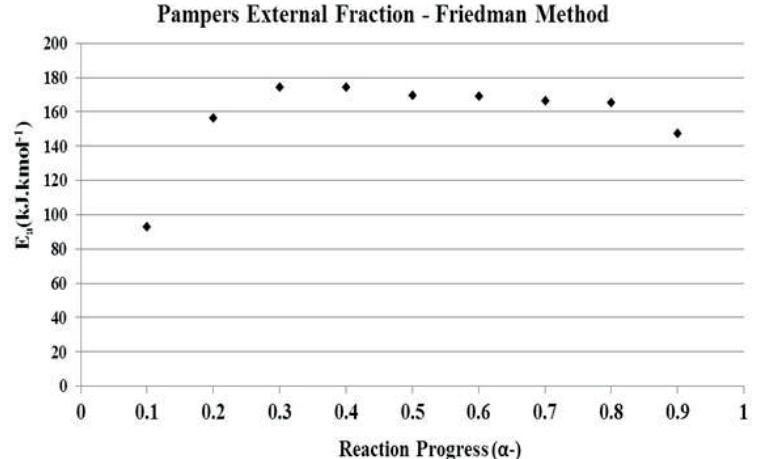

(b)

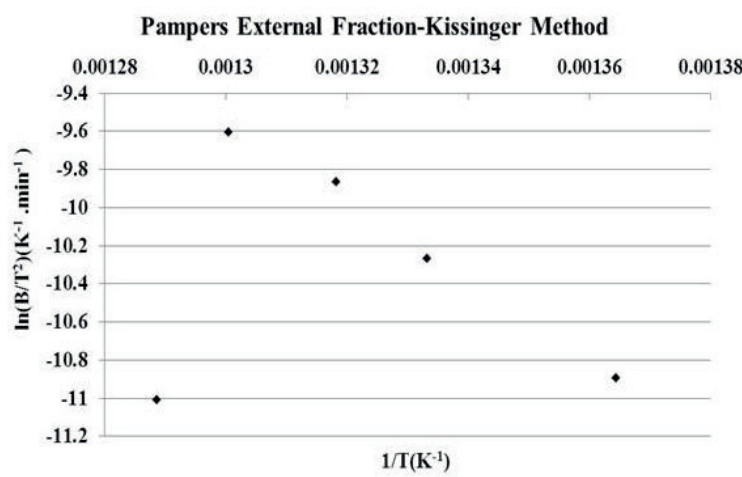

(d)

FIGURE 10: Pampers External Fraction kinetic parameters profiles (Friedman and Kissinger Methods). 
TABLE 3: Char residue for the Huggies and Pampers disposable diaper brands.

\begin{tabular}{|c|c|c|c|c|}
\hline \multirow{2}{*}{$\begin{array}{l}\text { Heating Rates } \\
\qquad\left({ }^{\circ} \mathrm{C} / \mathrm{min}\right)\end{array}$} & \multicolumn{4}{|c|}{ Disposable Diaper Brands - Char Residue (wt.\%) } \\
\hline & Huggies Interior Fraction & Huggies Exterior Fraction & Pampers Interior Fraction & Pampers Exterior Fraction \\
\hline 10 & 17.87 & 6.08 & 20.08 & 3.51 \\
\hline 20 & 22.43 & 8.03 & 24.32 & 3.73 \\
\hline 30 & 19.71 & 4.43 & 24.89 & 2.66 \\
\hline 40 & 21.14 & 7.10 & 21.92 & 3.22 \\
\hline 50 & 20.22 & 7.40 & 15.21 & 3.78 \\
\hline
\end{tabular}

TABLE 4: Kinetic parameters estimated using iso-conventional methods for Huggies and Pampers disposable diapers.

\begin{tabular}{|c|c|c|c|c|c|c|c|}
\hline \multirow{2}{*}{ Method } & \multirow{2}{*}{ Parameter } & \multicolumn{4}{|c|}{ Internal fraction } & \multicolumn{2}{|c|}{ External fraction } \\
\hline & & \multicolumn{2}{|c|}{ Huggies } & \multicolumn{2}{|c|}{ Pampers } & Huggies & Pampers \\
\hline \multirow{2}{*}{ Friedman } & $\mathrm{E}_{\mathrm{a}}(\mathrm{kJ} / \mathrm{mol})$ & \multicolumn{2}{|c|}{141.35382} & \multicolumn{2}{|c|}{109.31620} & 157.54123 & 159.71986 \\
\hline & $\mathrm{k}_{0}\left(\mathrm{~s}^{-1}\right)$ & \multicolumn{2}{|c|}{$1.29 \mathrm{E}+14$} & \multicolumn{2}{|c|}{$5.81 E+09$} & $9.56 \mathrm{E}+08$ & $3.98 E+09$ \\
\hline \multirow{2}{*}{ Kissinger } & $\mathrm{E}_{\mathrm{a}}(\mathrm{kJ} / \mathrm{mol})$ & \multicolumn{2}{|c|}{6.58618} & \multicolumn{2}{|c|}{122.04952} & 166.35620 & 164.99964 \\
\hline & $\mathrm{k}_{0}\left(\mathrm{~s}^{-1}\right)$ & \multicolumn{2}{|c|}{$1.59 \mathrm{E}+05$} & \multicolumn{2}{|c|}{$1.85 \mathrm{E}+40$} & $1.56 \mathrm{E}+07$ & $1.10 \mathrm{E}+07$ \\
\hline & & Peak 1 & Peak 2 & Peak 1 & Peak 2 & & \\
\hline \multirow{2}{*}{ Friedman } & $\mathrm{E}_{\mathrm{a}}(\mathrm{kJ} / \mathrm{mol})$ & 166.93548 & 59.05602 & 147.83615 & 157.07943 & & \\
\hline & $\mathrm{k}_{0}\left(\mathrm{~s}^{-1}\right)$ & $1.20 \mathrm{E}+12$ & $3.82 \mathrm{E}+02$ & $4.55 \mathrm{E}+12$ & $9.08 \mathrm{E}+08$ & & \\
\hline \multirow{2}{*}{ Kissinger } & $\mathrm{E}_{\mathrm{a}}(\mathrm{kJ} / \mathrm{mol})$ & 123.60424 & 160.62648 & 130.01433 & 93.03366 & & \\
\hline & $\mathrm{k}_{0}\left(\mathrm{~s}^{-1}\right)$ & $5.34 \mathrm{E}+05$ & $1.35 \mathrm{E}+07$ & $2.71 \mathrm{E}+06$ & $1.77 \mathrm{E}+02$ & & \\
\hline
\end{tabular}

refore, the final $\mathrm{E}_{\mathrm{a}}$ and $\mathrm{k}_{0}$ estimations are subsequently different. Hence, the differential approach (Friedman) is more accurate since differentiation can be carried out on every step of the reaction progress.

\section{CONCLUSIONS}

It has been illustrated that disposable diapers thermal treatment as a waste material recovery method is possible. Prior to processing, it is required that the diapers are separated into an internal fraction and external fraction since there are distinctive devolatilisation profiles between the two fractions. The present study also showed that disposable diapers consist mainly of volatile matter, while the ash content is relatively low. Furthermore, the interior fraction has a significant high volatile content which is a result of the materials contained in the inner layers of the diaper brands. Consequently, this further proves that disposal methods, such as landfilling and incinerating, are not suitable for disposable diapers. Subsequently, the interior fraction of the diaper can be further separated into two sub-fractions at it has two distinctive devolatilisation peaks that belong to the absorbent and bio-based material fraction. Therefore, step-wise recovery of the three main fractions, fossil-based (exterior fraction), bio-based (interior fraction fiber) and inorganic (interior fraction absorbent) need further investigation.

A precise study of the behaviour of the diapers under thermal treatment was further observed from different kinetic mechanism parameters obtained using iso-conventional methods, namely the Friedman and Kissinger methods. Since the Friedman method is independent of the heating rates as compared to the Kissinger method the
Friedman method is more applicable to the present study. Therefore, the present study has not only illustrated the potential for the recovery of valuable chemical and energy waste products but further demonstrated the separation and recovery of the products during thermal conversion.

\section{ACKNOWLEDGEMENTS}

This research was in part supported by the University Capacity Development Grant (UCDP) of The Department of Higher Education (DHET).

The authors acknowledge that opinions, findings and conclusions or recommendations expressed are those of the authors only, and the sponsors accept no liability whatsoever in this regard.

\section{REFERENCES}

Aboulkas, E., El Harfi, K., \& El Bouadili, A. (2010). Thermal degradation behaviour of polyethylene and polypropylene. Part 1: Pyrolysis kinetics and mechanism. Energy Conversion and Management, 51:1363-1369.

Achankeng, E. (2003). Globalization, urbanization and municipal solid waste management in Africa. In Proceedings of the African Studies Association of Australasia and the Pacific 26th Annual Conference (pp. 1-22), Adelaide, Australia. Retrieved from: http://www. wiego.org/sites/default/files/publications/files/Achankeng_Globalization Urbanization_MSWMgmt_Africa.pdf.

Apaydin-Varol, E., Polat, S., \& Putun, A. E. (2014). Pyrolysis Kinetics and Thermal Decomposition Behaviour of Polycarbonate - a TGA-FTIR study. Thermal Science, 18 (3): 833-842.

Arenas, C.N., Navarro, M .V., \& Martínez, J .D. (2019). Pyrolysis kinetics of biomass wastes using isoconversional methods and the distributed activation energy model. Bioresource Technology, 288: 1-11.

ASTM E1131-08. (2008). Standard Test Method for Compositional Analysis by Thermogravimetry. ASTM International, Pennsylvania, United States. 
Badgie, D., Samah, M. A. A., Manaf, L. A., \& Muda, A. B. (2012). Assessment of Municipal Solid Waste Composition in Malaysia: Management, Practice, and Challenges. Polish Journal of Environmental Studies, 21 (3): 539-547.

Budyk, Y. \& Fullana, A. (2019). Hydrothermal carbonization of disposable diapers. Journal of Environmental Chemical Engineering, 7: 1-7.

Chhabra, V., Shastri, Y., \& Bhattacharya, S. (2016). Kinetics of Pyrolysis of Mixed Municipal Solid Waste-A Review. Procedia Environmental Sciences, 35: $513-527$

Colon, J., Ruggieri, J., Gonzalez, A., Puig, I., \& Sanchez, A. (2011). Possibilities of composting diapers with municipal solid waste. Waste Management and Research, 29 (3): 249- 259.

David, V.E., Wenchaoa, J., Johna, Y., \& Mmerekib, D. (2019). Solid Waste Management in Monrovia, Liberia: Implications for Sustainable Development. The Journal of Solid Waste Technology and Management, 45 (1):102-110.

Hamad, T.A., Agll. A.A., Hamad, Y.M., \& Sheffield, J.W. (2014). Solid waste as renewable energy resource: current and future possibility in Libya. Caste Studies in Thermal Engineering, 4:144-152.

Heydari, M., Rahman, M., \& Gupta, R. (2015). Kinetic Study and Thermal Decomposition Behavior of Lignite Coal. International Journal of Chemical Engineering, 2015: 1-9.

Hicks, B. J. (2007). Lean information management: Understanding and eliminating waste. International Journal of Information Management, 27 (4): 233-249.

Hristovski, K., Olson, L., Hild, N., Peterson, D., \& Burge, S. (2007). The municipal solid waste system and solid waste characterization at the municipality of Veles, Macedonia. Waste Management, 27(11):1680-1689.

Idowu, I. A., Atherton, W., Hashim, K., Kot, P., Alkhaddar, R., Alo, B. I., \& Shaw, A. (2019). An analysis of the status of landfill classification systems in developing countries: Sub Saharan Africa landfill experiences. Waste Management, 87:761-771.

Kazuva, E. \& Zhang, J. (2019). Analysing Municipal Solid Waste Treatment Scenarios in Rapidly Urbanizing Cities in Developing Countries: The Case of Dar es Salaam, Tanzania. International Journal of Environmental Research and Public Health, 16 (11): 2035.

Khoo, S.C., Phang, X.Y., Ng, C .M., Lim, K. L., Lam, S .S., \& Ma. N, L. (2019). Recent technologies for treatment and recycling of used disposable baby diapers. Process Safety and Environmental Protection, 123:116-129.

Krafchik, B. (2016). History of diapers and diapering. International Journal of Dermatology, 55: 4-6.

Kyere, R., Addaney, M., \& Akudugu, J. A. (2019). Decentralization \& Solid Waste Management in Urbanizing Ghana: Moving beyond the Status Quo. In Municipal Solid Waste Management. DOI:10.5772/ intechopen.81894

Liang, L., Sun, R., Fei, J., Wu, S., Liu, X., Dai, K., \& Yao, N. (2008). Experimental study on effects of moisture content on combustion characteristics of simulated municipal solid wastes in a fixed bed. Bioresoure Technology, 99 (15): 7238-7246.

Marshall, R.E. \& Farahbakhsh, K. (2013). Systems approaches to integrated solid waste management in developing countries. Waste Management, 33 (4): 988-1003.

McKay, G. (2002). Dioxin characterisation, formation and minimisation during municipal solid waste (MSW) incineration. Chemical Engineering Journal, 86 (3): 343-368.
Mendoza, J. M. F., D’Aponte, F., Gualtieri, D., \& Azapagic, A. (2019). Disposable baby diapers: Life cycle costs, eco-efficiency and circular economy. Journal of Cleaner Production, 211: 455-467.

Mihajlović, M. A., Pešić, R. V., \& Jovanović, M. B. (2019). Framework of new landfill GHG policy in developing countries: Case study of Serbia. Greenhouse Gases: Science and Technology, 9 (2): 152-159.

Moore, L. (2019). Ambitions for Greening Solid Waste Management: Perspectives from Urban (ising) Africa. Retrieved from: https:// www.africaportal.org/publications/ambitions-greening-solid-waste-management-perspectives-urbanising-africa/.

Oelofse, S. \& Nahman, A. (2019). Waste as a resource: opportunities in Africa. ReSource, 21 (2): 23-27.

Perera, K.U.C. \& Narayana, M. (2018). Kissinger method: the sequential approach and DAEM for kinetic study of rubber and gliricidia wood. Journal of the National Science Foundation of Sri Lanka, 46 (2):187-196.

Pham, N.T. \& Brown, E.W. (2009). Diapers and the environment. NEARTA. Retrieved from: www.nearta.com

Remigios, M. V. (2014). The environmental health implications of the use and disposal of disposable child diapers in Senga/Nehosho suburb in Gweru City, Zimbabwe. Global Journal of Biology, Agriculture and Health Sciences, 3 (2):122-127.

Sharifzadeh, M., Sadeqzadeh, M., Guo, M., Borhani,T. N., Konda N.V.S.N.M.,Garcia, M.C., Wang, L., Hallet, J., \& Shah, N. (2019). The multi-scale challenges of biomass fast pyrolysis and bio-oil upgrading: Review of the state of art and future research directions. Progress in Energy and Combustion Science, 71: 1-80.

Sheila, S.P. (2016). Soiled diapers stuck in landfills. Star. Retrieved from .https://www.thestar.com.my/metro/community/2016/05/23/ soiled-diapers-stuck-in-landfills-recycling-is-the-way-forward-saysexpert/.

Smyth, D. P., Fredeen, A. L., \& Booth, A. L. (2010). Reducing solid waste in higher education: The first step towards 'greening'a university campus. Resources, Conservation and Recycling, 54 (11):1007-1016.

Sun, X., Li, J., Zhao, X., Zhu, B., \& Zhang, G. ( 2016). A review on the management of municipal solid waste fly ash in American. Procedia Environmental Science, 31: 535-540.

Topanou, N., Domeizel, M., Fatombi, J., Josse, R. G., \& Aminou, T. (2011). Characterization of household solid waste in the town of Abomey-Calavi in Benin. Journal of Environmental Protection, 2 (06): 692-699.

UNTHA UK. (2015). The industry heavyweights: Waste hierarchy vs Circular economy. Retrieved from: https://www.untha.co.uk/wp-content/uploads/2015/03/Circular-Economy-vs-Waste-Hierarchy.pdf.

Williams, P. T. (2005). Waste Treatment and Disposal. 2nd Edition. Chichester ,West Sussex, England, John Wiley \& Sons Ltd.

Wolston, C. 2015. What's in Disposable Diapers- and Are They Safe for Your Baby? Retrieved from: https://www.babycenter.com/0_whatsin-disposable-diapers-8211-and-are-they-safe-for-your_10335425. bc//

Zoeteman, B. C., Krikke, H. R., \& Venselaar, J. (2010). Handling WEEE waste flows: on the effectiveness of producer responsibility in a globalizing world. The International Journal of Advanced Manufacturing Technology, 47(5-8):415-436.

Zurbrugg, C. (2002). Urban solid waste management in low-income countries of Asia: How to cope with the garbage crisis. Presented for: Scientific Committee on Problems of the Environment (SCOPE) Urban Solid Waste Management Review Session, pp.1-13, Durban, South Africa. 